\title{
Performance of five rice (Oryza sativa L.) varieties as influenced by crop establishment under irrigated lowland conditions
}

\author{
Lutao, F.T. Jr. ${ }^{1}$ and D.M. Baňoc ${ }^{* 2}$ \\ ${ }^{1}$ Department of Agriculture, Regional Field Unit 8, Kanhuraw Hill, Tacloban City, Leyte, \\ Philippines \\ ${ }^{2}$ Department of Agronomy, Visayas State University, Visca, Baybay City, 6521 Leyte, \\ Philippines
}

\begin{abstract}
This study aimed to determine the growth and yield performance of five rice varieties under the different crop establishments and assess rice profitability as influenced by crop establishment under irrigated lowland conditions. The study was laid out in a split-plot arranged in an RCBD with three replications. Crop establishment was designated as the main plot while rice varieties as a sub-plot. Results revealed that the direct row seeding method showed a significant advantage in agronomic and yield and yield component parameters over the transplanting method among rice varieties tested. Heirloom red rice significantly headed earlier (63.17 days) when planted in both crop establishments and had the tallest plant height, greater leaf area index, the heavier weight of 1,000 grains, and higher grain yield. There was a significant interaction effect on crop establishment and rice variety recorded from sowing to heading and maturity. Cost and return analysis revealed that the direct row seeding method achieved higher gross income (USD2, 012.00) and gross margin (USD 1,086.60) than the transplanting method. Heirloom red rice significantly achieved the highest grain yield $(5.85 \mathrm{t}$ $\mathrm{ha}^{-1}$ ), resulting in a higher gross income and gross margin of USD 2,340.00 and USD 1,352.45, respectively. Direct row seeding is applicable as an effective cost-reducing method of crop establishment for lowland rice production. Besides, it can shorten the time of crop establishment. Heirloom red rice with dual characteristics as an irrigated lowland and upland rice cultivar is feasible for direct row seeding and transplanting methods during the dry season. Keywords: Direct row seeding; Gross margin; Lowland rice, Transplanting; Upland rice
\end{abstract}

\section{Introduction}

Rice (Oryza sativa L.) is the most cultivated crops for food production. This crop contributes significant importance to food security since more than half of the

\footnotetext{
*Corresponding author: D.M. Baňoc

Email: dionesio.banoc@vsu.edu.ph

Received: November 21, 2020;

Accepted: December 26, 2020;

Published: December 26, 2020.
}

world's population utilizes this as a primary staple food, the main source of energy and income (Fikriyah 2018). With the increasing population globally, the demand for rice also increases. However, rice production in the country is deficient due to the ill effects of climate change, declining rice areas due to land conversion, pests and diseases, and lack of irrigation facilities. In 
the supply of the food requirements for the growing populace, there is a need to solve rice insufficiency by enhancing rice production through better management practices. One of the solutions to increase production is through the improvement of crop establishment that can produce higher grain yield and, at the same time, the costreducing option to farmers, albeit climate change situation. Thereby, good crop establishment is an essential pre-requisite of satisfactory yields (Bleasdale 1982). Rice is grown under two crop establishment methods, such as transplanting and direct seeding. However, this crop is mainly affected by such methods. However, there are rice varieties that are feasible for growing in either or both of said methods. Knowing specific rice variety is a must to achieve higher productivity and production for an increasing population. Rice variety differs in their yield potential depending on their genetic makeup and the environment. It is vital to study the performance of five rice varieties that guarantee performance potential to provide a more significant advantage in crop management to effect higher yield and income under different crop establishment methods. Thus, in selecting appropriate varieties, factors affecting crop management such as soil type, planting method, fertilizer efficiency, rainfall, climate, and disease pressure should be considered (IRRI 2009). It is necessary to consider the appropriate rice varieties that can thrive well under adverse environmental conditions. High yield and acceptable grain quality for the market might result from a locally adapted variety and good crop establishment.

The choice of the method of crop establishment affects water use, the presence of weeds, and even the crop yield. The crop establishment method in irrigated lowland ecosystems is transplanting, commonly practiced during the wet season, whereas direct seeding is adopted mostly during the dry season (Fikriyah 2018). Rice farmers practically practice both methods in both seasons in the Philippines.

Changes in crop yield and production over time are driven by genetics, agronomic, and climate factors. Climate impacts on rice production are strongly seasonally modulated and differ considerably by region. Low rice supply and increasing demand affect food security and the country (Stuecker et al., 2018). Better design of management interventions in increasing productivity, identifying, and assessing constraints are necessary. One way of improving rice production and productivity is to adapt to climate change situations by identifying rice varieties that can thrive under adverse environmental conditions. Thereby, proper crop establishment in rice needs to be determined in every agro-ecological situation for rice production. This study aimed to examine and analyze the performance, efficiency, and profitability of the five rice varieties influenced by crop establishment under irrigated lowland conditions. Results were valuable in determining the growth and yield performance and the appropriate crop establishment of specific rice varieties under irrigated lowland conditions.

\section{Materials and Methods}

The experiment was implemented in an irrigated lowland farmer's field in Brgy. San Vicente, Ormoc City, Leyte, Philippines, where there is an adequate water source from January 10, 2020, to May 10, 2020. An experimental area of $404.32 \mathrm{~m}^{2}$ was plowed and harrowed twice at weekly 
intervals. Dikes and canals were constructed around each treatment plot to facilitate water management. Final paddling was done two days before transplanting and direct row seeding.

The experiment was laid out in a splitplot arranged in a Randomized Complete Block Design (RCBD) with three replications. Crop Establishment was designated as the main plot, while five rice varieties as the subplot. Each replication was divided into two main plots with five subplots. The subplot dimension was $2 \mathrm{~m} \times$ $5 \mathrm{~m}$, with 250 hills spaced at $20 \mathrm{~cm} \times 20$ $\mathrm{cm}$. A 1.0-meter alleyway separated each replication while both the main-plot and sub-plot were provided with corresponding alleyways of $40 \mathrm{~cm}$ to facilitate farm operation and management and data gathering. The specific treatments were designated as follows: Main-plot (Crop Establishment): $\mathrm{M}_{1}=$ Direct Row Seeding and $\mathrm{M}_{2}=$ Transplanting. Sub-plot (Rice Variety): $\mathrm{T}_{1}=$ NSIC Rc216, $\mathrm{T}_{2}=$ NSIC Rc222, $\mathrm{T}_{3}=$ NSIC Rc400, $\mathrm{T}_{4}=\mathrm{NSIC}$ Rc402, and $\mathrm{T}_{5}=$ Heirloom red rice.

Ten soil samples from the experimental fields were randomly collected before land preparation and after harvest at a depth of 0 - $20 \mathrm{~cm}$. Samples were air-dried, pulverized, and sieved to pass through a 2 $\mathrm{mm}$ wire mesh and mixed thoroughly to make a composite sample. Composite samples were placed in bags and labelled. There was one composite sample for initial and ten composite samples from three replications at the sampling plot after harvest. The mixed soil sample was submitted to the Central Analytical Services Laboratory (CASL), Philippine Root crops Research and Training Center (PhilRootcrops), Visayas State University, Visca, Baybay City, Leyte, Philippines, for analyses in soil $\mathrm{pH}$ through potentiometer method (PCARR 1980), \% organic matter through Modified Walkley-Black Method (ISRIC 1995), total nitrogen through Kjeldahl method (Nelson and Sommers 1982), extractable $P$ thru Modified Olsen Method (Olsen et al., 1954), and exchangeable $\mathrm{K}$ by ammonium acetate extraction method (ISRIC 1995).

\section{Crop Establishment}

The time of pre-germination on both transplanting and direct row seeding method were done simultaneously. It was done by sowing the pre-germinated rice seeds on the seedbed to transplant and sowing of pre-germinated seeds in the rice field for direct row seeding.

\section{Direct Row Seeding Method}

Pre-germinated rice seeds of about 216 grams per variety were used following the seed requirement of $80 \mathrm{~kg} \mathrm{ha}^{-1}$ and were sown at a distance of $20 \mathrm{~cm} \times 20 \mathrm{~cm}$ at the seeding rate of four to five seeds hill $^{-1}$. Replanting of missing hills and thinning were done one week after sowing, remaining two seedlings per hill. Necessary care and management were provided to the growing seedlings until they could survive and adapt to the environment.

\section{Transplanting Method}

Rice seeds of 150 grams per variety were used in the experiment following the seeding rate of $40 \mathrm{~kg} \mathrm{ha} \mathrm{h}^{-1}$ and a recommended seedbed area of $400 \mathrm{~m}^{2}$ hectare $^{-1}$. Seeds were soaked in tap water for 24 hours and incubated for 48 hours before they were sown in the seedbed. A wet-bed with an area of $4.8 \mathrm{~m}^{2}(1 \mathrm{~m} \times 4.8 \mathrm{~m})$ with drainage around the bed was prepared. The seedbed was divided into five subplots, and pre-germinated seeds of each variety were uniformly distributed into the said wet-bed. Necessary care and management were provided to the seedlings, such as 
irrigating the seedbed gradually and continuously to a depth of five $\mathrm{cm}$ depending on the seedlings' height until they were ready for transplanting. Nets were installed to protect them from stray animals and birds. Then, the seedlings were maintained for 15 days beforehand, pulling and transplanting to the intended plots.

\section{Transplanting}

Seedlings of identified five rice varieties were transplanted 15 days after sowing at two seedlings per hill spaced at $20 \mathrm{~cm} \times 20$ $\mathrm{cm}$. Replanting of missing hills was done three to five days after transplanting. Necessary care and management were provided to the growing seedlings until they could survive and adapt to the environment.

\section{Fertilizer Application}

Rice plants were applied with inorganic fertilizer using complete fertilizer (14-1414) and urea (46-0-0) at the rate of 120-60$60 \mathrm{~kg} \mathrm{ha}^{-1} \mathrm{~N}, \mathrm{P}_{2} \mathrm{O}_{5}$, and $\mathrm{K}_{2} \mathrm{O}$. The fertilizers were applied simultaneously in both crop establishment methods. In the transplanting method, complete fertilizer was used at the rate of $60-60-60 \mathrm{~kg} \mathrm{ha}^{-1}$ of $\mathrm{N}, \mathrm{P}_{2} \mathrm{O}_{5}$, and $\mathrm{K}_{2} \mathrm{O}$ by broadcasting the actual amount (428.57 grams plot $^{-1}$ ) twelve days after transplanting. In the direct row seeding method, complete fertilizer was applied at the same rate of $\mathrm{N}, \mathrm{P}_{2} \mathrm{O}_{5}$, and $\mathrm{K}_{2} \mathrm{O}$ by broadcasting the actual amount (428.57 grams plot ${ }^{-1}$ ) 27 days after sowing. The remaining $\mathrm{N}$ was top-dressed (130.34 grams plot $^{-1}$ ) at the panicle initiation (PI) stage of each variety in both methods.

\section{Water Management}

To easily manage irrigation water in the experimental field, dikes around each treatment plot were constructed to impound water. Canals were constructed around the experimental plot to drain excess water during heavy rainfall. Irrigation water was supplied simultaneously in both direct row seeding and transplanting method. Intermittent irrigation was adopted in both methods. For the direct row seeding method, irrigation water of two to three $\mathrm{cm}$ depth was supplied in plots ten days after sowing and was increased its depths gradually depending on the height of seedlings. For the transplanting method, irrigation water of two to three $\mathrm{cm}$ depth was supplied at the seedbed ten days after sowing and was gradually increased its depths depending on the height of the seedlings.

\section{Weed Management}

Weeding in transplanting and direct row seeding method were manipulated simultaneously. In the transplanting method, rotary weeding was conducted ten days after transplanting to control weeds in the experimental area. It was followed by hand weeding one week later to remove the weeds around the hills altogether. Then subsequent weeding operations were done to eliminate the weeds and continuously done until the plant canopy closed in.

For direct row seeding, rotary weeding was manipulated 25 days after sowing and repeated in a crisscross manner. Hand weeding was conducted one week after row weeding operation to remove the weeds around the hills altogether.

\section{Pest Management}

Molluscicide was applied one day before crop establishment in both direct row seeding and transplanting methods. To prevent kuhol or golden apple snail infestation, handpicking of adults and egg masses of golden apple snail (Pomacea canaliculata L.) was done before and after transplanting and also after sowing for the direct row seeding method. Pesticides were sprayed to control insect pests and diseases. It was done by spraying 25 grams Lannate (Methomyl) mixed with 16 liters of water to 
prevent rice bugs when one to two insects hill $^{-1}$ were observed at the heading stage. In controlling fungal and bacterial diseases, spraying of fungicides and bactericides was done to prevent infections of said diseases.

\section{Harvesting}

Lowland rice was harvested when approximately $85 \%$ of the grains in each treatment plot attained at the ripening stage, as indicated by the yellow or golden colour of the grains, firm, and hard grains. All sample plants within the harvestable area were cut at the base using a sickle, excluding one border row on each side of the plot and two end hills at both ends of each row. Harvested plants were threshed, winnowed, sun-dried for three days, and tested for seed moisture using a seed moisture tester before data gathering.

\section{Gathered Data}

\section{Agronomic Parameters}

The data gathered were the number of days from sowing to heading, days from sowing up to $50 \%$ heading, and the number of days from planting to maturity.

Plant height $(\mathrm{cm})$ at heading, fresh straw yield, and the Leaf Area Index (LAI) determined at the heading stage when $50 \%$ of the panicles have partially exerted from the boot. LAI was initially determined by measuring first the length and width of each sample leaf collected from the middle tiller, and the area of each leaf computed using the formula:

Leaf area $=$ length $\mathrm{x}$ width $\mathrm{x}$ correction factor.

The sum of all leaf areas is considered as the total leaf area in each hill. It computed using the formula:

Total leaf area hill- ${ }^{-1}=$ Mean leaf area of the middle tiller $\times$ total number of tillers The leaf area index (LAI) computed using the formula:

\section{LAI = \\ Total Leaf Area (Five hills)}

$\overline{\text { Ground area covered by five hills }\left(2,000 \mathrm{~cm}^{2}\right)}$

Each rice variety's correction factor was established wherein the middle tillers from ten randomly selected hills of each variety were used. The functional leaves from ten sample middle tillers of each variety were collected by cutting at the collar using scissors. Each leaf is traced on a paper. The longest length and broadest width were the bases of drawing a rectangle in every traced leaf sample. The total weight of all paper cut in rectangles was determined and divided by the total number of rectangles to get the weight per rectangle (WT). All traces of leaves were cut out based on actual leaf shape and weighed. The total weight was divided by the total number of cut outs to get the weight per actual traced leaf cut out (AT).

The correction factor was determined using the formula:

$\frac{\mathrm{CF}}{\text { Weight of actual traced leaf (AT) }}=$

\section{Yield and Yield Component Parameters}

Data gathered were the number of productive tillers per hill, percentage filled spikelets, panicle length $(\mathrm{cm})$, panicle weight $(\mathrm{g})$ hill $^{-1}$, weight $(\mathrm{g})$ of 1,000 grains, and grain yield $\left(\mathrm{t} \mathrm{ha}^{-1}\right)$.

\section{Cost and Return Analysis}

The profitability of the growing five rice varieties was determined as influenced by crop establishment method under irrigated lowland conditions. The total variable cost was determined by recording all the variable expenses incurred from land preparation until drying. These include the cost of fertilizers, seeds, and other materials, as well as labour.

\section{Statistical Analysis}


After gathering all the data, means were computed, and analysis of variance (ANOVA) was done using the Statistical Analysis System (SAS Version 6.12). A comparison of means was made using the Honestly Significant Difference (HSD) or Tukey's test.

\section{Meteorological Data}

The data on weekly rainfall $(\mathrm{cm})$, daily minimum and maximum temperatures $\left({ }^{\circ} \mathrm{C}\right)$, relative humidity (\%), and sunshine duration throughout the study were taken from the Ormoc City Climate Information Center, Department of Agriculture, Brgy. San Pablo, Ormoc City, Leyte, Philippines.

\section{Results and Discussion}

Climatic data showed that the highest rainfall was observed in the fourth week (Feb. 3 - 9, 2020), with total weekly precipitation of $32.90 \mathrm{~mm}$ per week. No rain was recorded in the third week (January 27 - February 2, 2020). The total rainfall showed that the average weekly rainfall was below the requirement needed for rice production. Thus, the amount of precipitation recorded was not adequate in supplying the necessary water requirements of the crop. Water deficits adversely affect many physiological processes such as stomatal closure, root shoot ratio increase, leaf area reduction, and osmotic adjustments in plants (Kaya et al., 2006). However, the limited rainfall did not affect crop growth and development since irrigation water was available for crop utilization. The average minimum and maximum temperatures were $26.17^{\circ} \mathrm{C}$ and $27.16^{\circ} \mathrm{C}$, respectively. According to Yin et al. (1996), as cited by Bañoc (2019), the optimum temperature for the normal development of rice ranges from $27^{\circ} \mathrm{C}$ to $30^{\circ} \mathrm{C}$. Thus, the temperature values conformed to the temperature requirements for normal vegetative and reproductive growth stages and rice crop development, ranging from $20-38^{\circ} \mathrm{C}$ from planting to harvesting (Luh 1980). The highest average relative humidity per week was recorded on the tenth week (March $16-22,2020$ ), with a relative humidity of $86.57 \%$. The total sunshine duration attained 5,855.72 minutes during the crop growing period and recorded with an average weekly sunshine duration of 344.45 minutes. The highest full minutes of sunshine were pointed out on the seventh week (February 24 - March 1, 2020), with a total of 504.53 minutes per day. The lowest was in the sixth week (Feb.17 - 23, 2020), with 264.93 minutes per day.

Weed proliferation was observed faster in the direct row seeding than in the transplanting method. They were prevalent in both crop establishments wherein the species of weeds observed were barnyard grass (Echinocloa crusgalli), jungle rice (Echinocloa colonum), purple nutsedge (Cyperus rotundus), and itch grass (Rottboellia cochinchinensis). Weeds were easily controlled by rotary weeding due to the availability of irrigation water in the area. Hand weeding was also performed in both crop establishment methods to completely remove the remaining weeds to avoid crop - weed competition. Weeds compete with the crop for light, nutrients, water, and space in the absence of standing water because both seeds of crops and weeds emerged almost simultaneously. According to Chhokar et al. (2014), directseeded rice exhibited severe weed infestation compared to transplanting, and it showed yield reduction with the presence of weeds. The yield reduction was due to weed infestation in direct-seeded rice ranged 
from 91.4 to $99.0 \%$, compared to 16.0 and $42.0 \%$ in the transplanting method.

At the reproductive stage, rice bugs only infest NSIC Rc400 (late-maturing variety) because said variety is late in harvesting. However, said variety was controlled by spraying twice of Lannate (Methomyl) at 25 grams mixed with 16 litres of water during the heading stage and one week after that to minimize the crop's damage by the said pest.

\section{Soil Chemical Properties}

The initial soil analysis result showed that the soil had a $\mathrm{pH}$ of $7.99,5.21 \%$ organic matter, total nitrogen of $0.57 \%$, $145.52 \mathrm{mg} \mathrm{kg}^{-1}$ available phosphorus, and $0.29 \mathrm{me} 100 \mathrm{~g}^{-1}$ exchangeable potassium. The result implies that the soil was strongly alkaline, the medium amount in organic matter, high amount in total nitrogen $(\mathrm{N})$, very high amount of available phosphorus, and medium amount in exchangeable potassium (Landon 1991). The result implies that the lowland soil is fertile; however, some essential nutrients required by plants were fixed due to high $\mathrm{pH}$, such as $\mathrm{P}$ fixation when soil $\mathrm{pH}$ is alkaline, making some essential elements unavailable. According to Fageria et al. (2011), the anaerobic soil environment created by flooding in the lowland ecosystem brings several chemical changes in the rhizosphere that may influence growth and development and, consequently, yield. The decreased $\mathrm{pH}$ in alkaline soil reduced redox potential and increased manganese concentrations, reducing nitrate and nitrogen dioxide to dinitrogen and nitrous oxide, reducing sulphate to sulphide, and reducing carbon dioxide methane in improvement in phosphorous concentrations.

For the final soil analysis, the soil $\mathrm{pH}$ decreases. The decreased soil $\mathrm{pH}$ might be attributed to the nitrification process from the applied nitrogen fertilizer. The hydrogen ion is released; as the percentage of ammonium increases in a given, the acidifying potential will also increase, reducing $\mathrm{pH}$ (www.blinc.com). The increasing total $\mathrm{N}$ may be due to the decreasing soil $\mathrm{pH}$ to a neutral level that provided more available nitrogen in the soil. The crop itself had used up the nitrogen applied to the rice crop during vegetative and reproductive growth phases. However, a decrease in the organic matter might be due to the crop residues that were not yet thoroughly decomposed and a crop's possible utilization at the different growth stages. Further, a decrease in available $\mathrm{P}$ could be due to leaching caused by irrigation water and the rice crop's actual utilization for its growth and development.

\section{Agronomic Characteristics}

Analysis of variance revealed that the number of days from sowing to heading and maturity was significantly influenced by crop establishment irrespective of rice varieties. However, plant height $(\mathrm{cm})$, LAI, and fresh straw yield $\left(\mathrm{t} \mathrm{ha}^{-1}\right)$ were not significantly affected by crop establishment. Relative to the different varieties tested, all agronomic parameters were significantly affected (Table 1). An interaction effect between establishment and rice variety was recorded considerably on the number of days from sowing to heading and maturity and LAI (Tables 2 4).

Regardless of variety, lowland ricegrowing under direct row seeding method had significantly headed earlier (73.53 days) than those grown in transplanting method with 77.73 days. Similarly, plants under direct row seeding matured significantly earlier (100.60 days) than those under the transplanting method with 
104.60 days. Results conformed to the study of Yoshida 1981 that direct-seeded rice attained earlier tillering than transplanting because its seedling growth of the former was not affected by root injury through uprooting of seedlings. Kumar et al. (2008) observed that direct seeding of sprouted seeds under paddled conditions is favourably influenced by the growth

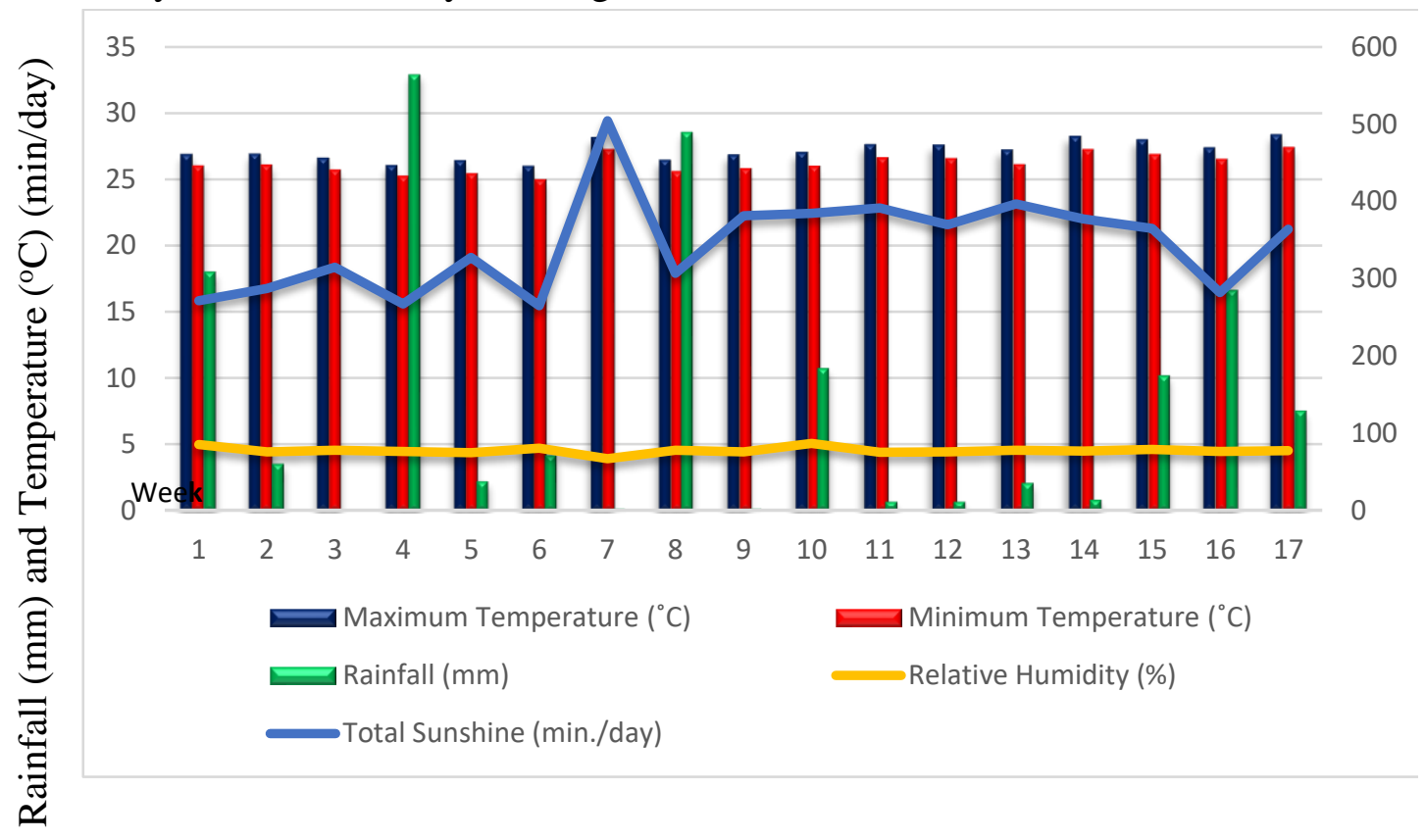



Figure 1. The agro-meteorological data during the conduct of the study (Source:

Ormoc Information, Climate Center, DA, San Pablo, Ormoc City, Leyte), Philippines 
Table 1. Agronomic characteristics of five rice (Oryza sativa L.) varieties as influenced by crop establishment under irrigated lowland conditions

\begin{tabular}{|c|c|c|c|c|c|}
\hline \multirow[t]{2}{*}{ Treatment } & \multicolumn{2}{|c|}{$\begin{array}{l}\text { Number of days from } \\
\text { sowing to }\end{array}$} & \multirow{2}{*}{$\begin{array}{l}\text { Plant } \\
\text { height } \\
(\mathrm{cm})\end{array}$} & \multirow{2}{*}{$\begin{array}{l}\text { Leaf Area } \\
\text { Index }\end{array}$} & \multirow{2}{*}{$\begin{array}{c}\text { Fresh straw } \\
\text { yield } \\
\left(\mathrm{t} \mathrm{ha}^{-1}\right)\end{array}$} \\
\hline & Heading & Maturity & & & \\
\hline \multicolumn{6}{|l|}{ Crop establishment } \\
\hline $\mathrm{M}_{1}=$ Direct row seeding & $73.53 b$ & $100.60 \mathrm{~b}$ & 87.60 & 2.08 & 14.34 \\
\hline $\mathbf{M}_{2}=$ Transplanting & $77.73 \mathrm{a}$ & $104.60 \mathrm{a}$ & 87.12 & 2.13 & 14.17 \\
\hline Mean & 75.63 & $102.60 \mathrm{a}$ & 87.36 & 2.11 & 14.26 \\
\hline \multicolumn{6}{|l|}{ Rice variety } \\
\hline $\mathrm{T}_{1}=\mathrm{NSIC} \mathrm{Rc} 216$ & $73.00 \mathrm{c}$ & $102.50 \mathrm{~b}$ & $80.02 \mathrm{c}$ & $2.05 \mathrm{~b}$ & $12.61 b$ \\
\hline $\mathrm{T}_{2}=\mathrm{NSIC} \mathrm{Rc} 222$ & $77.33 b$ & $103.50 \mathrm{~b}$ & $84.13 \mathrm{c}$ & $2.14 \mathrm{ab}$ & $13.25 \mathrm{~b}$ \\
\hline $\mathrm{T}_{3}=\mathrm{NSIC} \mathrm{Rc} 400$ & $91.00 \mathrm{a}$ & $117.00 \mathrm{a}$ & $92.23 b$ & $2.36 \mathrm{ab}$ & $17.03 \mathrm{a}$ \\
\hline $\mathrm{T}_{4}=\mathrm{NSIC}$ Rc402 & $73.67 b$ & $99.00 \mathrm{c}$ & $78.29 \mathrm{c}$ & $1.54 \mathrm{c}$ & $12.91 \mathrm{~b}$ \\
\hline $\mathrm{T}_{5}=$ Heirloom red rice & $63.17 d$ & $91.00 \mathrm{~d}$ & $102.11 \mathrm{a}$ & $2.45 \mathrm{a}$ & $14.72 \mathrm{ab}$ \\
\hline Mean & 80.31 & 113.42 & 113.81 & 1.34 & 17.58 \\
\hline C.V. (a) $\%$ & 0.42 & 0.81 & 2.45 & 14.84 & 6.19 \\
\hline C.V. (b)\% & 1.08 & 0.62 & 5.21 & 9.03 & 12.40 \\
\hline$(\mathrm{CE} \times \mathrm{RV})$ & $* *$ & $* *$ & ns & $*$ & ns \\
\hline
\end{tabular}

The mean within the column followed by the same letter is not significantly different at the 5\% level, HSD.

$n s-$ not significant $\quad *$-significant $* *$ - highly significant

Gangwar et al. (2008) found that rice plants grown in drum seeding had a higher accumulation of dry biomass of shoot and root than the rice plants grown in manual and mechanical transplanting in a puddle condition. According to Sharma (1995), direct-seeded crops showed better initial establishment and gave higher grain yield than transplanted crops. Further, Naklang et al. (1996) stipulated that direct seeding produced higher total dry matter than transplanting. Five lowland rice varieties were grown under the direct row seeding method of crop establishment significantly headed and matured earlier than the transplanting method, maybe because of minimal stress in direct-seeded seedlings compared to transplanted seedlings. Relative to the different rice varieties tested, Heirloom red rice headed and matured significantly earlier than all other varieties tested irrespective of crop establishment. On the other hand, NSIC Rc400 headed and matured remarkably late at 91 days and 117 days.

The plant height depicts the plant's health and vigour, and it is directly proportional to the development of the root system. Regardless of crop establishment, Heirloom red rice remarkably grew tallest in plant height $(102.11 \mathrm{~cm})$ than those of other lowland rice varieties tested. However, NSIC Rc402 significantly achieved the shortest plant height $(78.29 \mathrm{~cm})$ but comparable to NSIC Rc222 and NSIC Rc216 with 84.13 $\mathrm{cm}$ and $80.02 \mathrm{~cm}$, respectively. In terms of LAI among the tested varieties, Heirloom red rice significantly achieved the highest LAI (2.45) and is comparable to NSIC Rc400 and NSIC Rc222 with 
LAI values 2.362.14, respectively. Further, NSIC Rc402 gave the lowest LAI value of 1.54. Leaf area is vital for crop light interception and radiation use efficiency. Therefore, this parameter can considerably influence plant growth (Boote et al., 1988). Relative to the fresh straw yield of five lowland rice varieties, NSIC Rc400 significantly produced the heaviest fresh straw yield with $17.07 \mathrm{t} \mathrm{ha}^{-}$ ${ }^{1}$ than all other varieties except Heirloom red rice with a fresh straw yield of $14.72 \mathrm{t}$ $\mathrm{ha}^{-1}$.

The significant interaction between crop establishment and rice varieties was noted on the number of days from sowing to heading, days to maturity, and LAI presented in Tables 2 - 4. Statistical analysis revealed that direct row seeding significantly headed earlier in all lowland rice varieties except NSIC Rc222 than that of the transplanting method. However, the heading of the NSIC Rc222 was not affected by the two methods of crop establishment (Table 2). Interaction between crop establishment and rice varieties on the number of days from sowing to maturity is presented in Table 3. All rice varieties matured remarkably earlier when established under direct row seeding than that of transplanting. However, the effect was more evident for NSIC Rc216 and Heirloom red rice when grown under direct row seeding compared to all other rice varieties tested.

A study by Mishra and Singh (2011) revealed that besides the early maturity of the crop under the direct-seeded method, it allows timely sowing of subsequent crops to produce a higher yield than transplanting. Interaction between crop establishment and rice varieties was observed in the leaf area index (LAI) of five lowland rice varieties tested (Table
4). Regardless of methods, the adoption of crop establishment significantly reduced the LAI values of NSIC Rc402 than those of all other rice varieties tested. However, the adoption of direct row seeding of NSIC Rc402 gave LAI comparable to NSIC Rc222, while the adoption of the transplanting method of NSIC Rc216 resulted in an LAI similar to NSIC Rc402. The increased LAI may be due to the higher solar radiation during the growing period. According to Ewert (2004), the variation in productivity and growth is closely linked to the amount of intercepted radiation, which is primarily determined by the leaf area index. Thereby, grain yield increased with an increase in LAI (Zheng et al., 2020). Yield and Yield Components

Analysis of variance revealed that the number of productive tillers, panicle length $(\mathrm{g})$, and grain yield $\left(\mathrm{t} \mathrm{ha}^{-1}\right)$ were significantly influenced by crop establishment regardless of lowland rice varieties tested (Table 5). However, percent filled spikelets, panicle weight $(\mathrm{g})$, weight $(\mathrm{g})$ of 1,000 grains were not significantly affected by crop establishment. Relative to five lowland rice varieties tested, most of the yield an yield components were influenced considerably by crop establishment except for the number of productive tillers per hill and panicle weight per hill, as reflected in Table 5. Regardless of lowland rice varieties tested, rice plants grown under the direct row seeding method significantly produced a higher number of productive tillers with 11.44 than those in the transplanting method with 10.16 productive tillers per hill. Similarly, the direct row seeding method significantly obtained a longer panicle length of $25.24 \mathrm{~cm}$ than those of the 
transplanted method $24.29 \mathrm{~cm}$. Moreover, plants was significantly higher with $5.03 \mathrm{t}$ grain yield produced in direct-seeded $\mathrm{ha}^{-1}$ than those in transplanting.

Table 2. Interaction between crop establishment and rice varieties on the number of days from sowing to heading of five rice (Oryza sativa L.) varieties as influenced by crop establishment under irrigated lowland conditions

\begin{tabular}{lcc}
\hline \multirow{2}{*}{ Rice variety } & \multicolumn{2}{c}{ Crop establishment } \\
\cline { 2 - 3 } & Direct row seeding & Transplanting \\
\hline $\mathrm{T}_{1}$-NSIC Rc216 & $70.33 \mathrm{~d}$ & $75.67 \mathrm{c}$ \\
$\mathrm{T}_{2}$ - NSIC Rc222 & $77.00 \mathrm{c}$ & $77.67 \mathrm{c}$ \\
$\mathrm{T}_{3}$ - NSIC Rc400 & $88.33 \mathrm{~b}$ & $93.67 \mathrm{a}$ \\
$\mathrm{T}_{4}$ - NSIC Rc402 & $70.33 \mathrm{~d}$ & $77.00 \mathrm{c}$ \\
$\mathrm{T}_{5}$ - Heirloom Red Rice & $61.67 \mathrm{f}$ & $64.67 \mathrm{e}$ \\
\hline
\end{tabular}

Means across crop establishment and rice varieties followed by the same letter are not significantly different at $5 \%$ HSD

Table 3. Interaction between crop establishment and rice varieties on the number of days from sowing to maturity of five rice (Oryza sativa L.) varieties as influenced by crop establishment under irrigated lowland conditions

\begin{tabular}{lcc}
\hline \multirow{2}{*}{ Rice Variety } & \multicolumn{2}{c}{ Crop Establishment } \\
\cline { 2 - 3 } & Direct Row Seeding & Transplanting \\
\hline $\mathrm{T}_{1}$-NSIC Rc216 & $99.33 \mathrm{e}$ & $105.67 \mathrm{c}$ \\
$\mathrm{T}_{2}$ - NSIC Rc222 & $101.67 \mathrm{~d}$ & $105.33 \mathrm{c}$ \\
$\mathrm{T}_{3}$ - NSIC Rc400 & $116.00 \mathrm{~b}$ & $118.00 \mathrm{a}$ \\
$\mathrm{T}_{4}$ - NSIC Rc402 & $96.67 \mathrm{f}$ & $101.33 \mathrm{~d}$ \\
$\mathrm{~T}_{5}$ - Heirloom Red Rice & $89.33 \mathrm{~h}$ & $92.67 \mathrm{~g}$ \\
\hline
\end{tabular}

Means across crop establishment and rice varieties followed by the same letter are not significantly different at $5 \%$ HSD

Table 4. Interaction between crop establishment and rice variety on leaf area index of five rice (Oryza sativa L.) varieties as influenced by crop establishment under irrigated lowland conditions

\begin{tabular}{lcc}
\hline \multirow{2}{*}{ Rice variety } & \multicolumn{2}{c}{ Crop establishment } \\
\cline { 2 - 3 } & Direct row seeding & Transplanting \\
\hline $\mathrm{T}_{1}=$ NSIC Rc216 & $2.25 \mathrm{ab}$ & $1.85 \mathrm{bc}$ \\
$\mathrm{T}_{2}=$ NSIC Rc222 & $2.07 \mathrm{abc}$ & $2.20 \mathrm{ab}$ \\
$\mathrm{T}_{3}=$ NSIC Rc400 & $2.38 \mathrm{ab}$ & $2.34 \mathrm{ab}$ \\
$\mathrm{T}_{4}=$ NSIC Rc402 & $1.49 \mathrm{c}$ & $1.58 \mathrm{c}$ \\
$\mathrm{T}_{5}=$ Heirloom red rice & $2.21 \mathrm{ab}$ & $2.68 \mathrm{a}$ \\
\hline
\end{tabular}

Means across crop establishment and rice varieties followed by the same letter are not significantly different at $5 \%$ $H S D$ 
Table 5. Number of productive tillers, percentage filled spikelets, panicle length $(\mathrm{cm})$, panicle weight $(\mathrm{g})$, weight $(\mathrm{g})$ of 1,000 grains, grain yield $\left(\mathrm{t} \mathrm{ha}^{-1}\right)$ of five rice (Oryza sativa $\mathrm{L}$.) varieties as influenced by crop establishment under irrigated lowland conditions

\begin{tabular}{|c|c|c|c|c|c|c|}
\hline Treatment & $\begin{array}{l}\text { ıber of productive tillers } \\
\text { per hill }\end{array}$ & $\begin{array}{c}\text { Percentage } \\
\text { filled } \\
\text { spikelets }\end{array}$ & $\begin{array}{l}\text { Panicle length } \\
\text { (cm) }\end{array}$ & $\begin{array}{l}\text { Panicle weight } \\
\left(\mathrm{g} \mathrm{hill}^{-1}\right)\end{array}$ & $\begin{array}{l}\text { Weight }(\mathrm{g}) \text { of } \\
1,000 \text { grains }\end{array}$ & $\begin{array}{l}\text { Grain yield } \\
\left(\mathrm{t} \mathrm{ha}^{-1}\right)\end{array}$ \\
\hline \multicolumn{7}{|l|}{ Crop establishment } \\
\hline $\mathrm{M}_{1}=$ Direct row seeding & $11.44 \mathrm{a}$ & 77.63 & $25.24 \mathrm{a}$ & 23.78 & 25.43 & $5.03 \mathrm{a}$ \\
\hline $\mathbf{M}_{2}=$ Transplanting & $10.16 b$ & 76.08 & $24.29 \mathrm{~b}$ & 23.42 & 25.15 & $4.19 \mathrm{~b}$ \\
\hline Mean & 10.80 & 76.86 & 24.77 & 23.60 & 25.29 & 4.61 \\
\hline \multicolumn{7}{|l|}{ Rice varieties } \\
\hline $\mathrm{T}_{1}=\mathrm{NSIC} \mathrm{Rc} 216$ & 10.48 & $83.32 \mathrm{a}$ & $25.38 \mathrm{ab}$ & 21.03 & $27.30 \mathrm{a}$ & $4.22 b$ \\
\hline$=$ NSIC Rc222 & 12.13 & $75.40 \mathrm{~b}$ & $25.14 \mathrm{ab}$ & 25.17 & $24.43 \mathrm{a}$ & $4.63 \mathrm{a}$ \\
\hline $\mathrm{T}_{3}=\mathrm{NSIC} \mathrm{Rc} 400$ & 9.87 & $66.19 \mathrm{c}$ & $26.67 \mathrm{a}$ & 22.64 & $21.58 b$ & $4.21 \mathrm{~b}$ \\
\hline $\mathrm{T}_{4}=\mathrm{NSIC} \mathrm{Rc} 402$ & 10.93 & $83.71 \mathrm{a}$ & $22.66 \mathrm{c}$ & 20.03 & $25.48 \mathrm{a}$ & $4.15 b$ \\
\hline $\mathrm{T}_{5}=$ Heirloom red rice & 10.60 & $75.66 b$ & $23.98 b c$ & 29.14 & $26.65 a$ & $5.85 \mathrm{a}$ \\
\hline Mean & 10.80 & 76.86 & 24.77 & 23.60 & 25.29 & 4.61 \\
\hline C.V. (a) $\%$ & 4.57 & 8.50 & 4.13 & 10.11 & 6.16 & 12.06 \\
\hline C.V. (b)\% & 14.76 & 4.95 & 3.72 & 22.05 & 8.69 & 16.41 \\
\hline$(\mathrm{CE} \times \mathrm{RV})$ & $\mathrm{Ns}$ & $\mathrm{ns}$ & $\mathrm{ns}$ & ns & $\mathrm{ns}$ & $\mathrm{ns}$ \\
\hline
\end{tabular}

The mean within a column followed by the same letter are not significantly different at the $5 \%$ level, $H S D$

$n s-$ not significant $*$-significant $* *$ - highly significant 


\section{Cost and Return Analysis}

The cost and return analysis of rice (Oryza sativa L.) as influenced by crop establishment and rice varieties under irrigated lowland conditions (Table 6). Relative to 1,000 grains, NSIC Rc216 significantly achieved the heaviest weight of 1,000 grains with $27.30 \mathrm{~g}$ than NSIC Rc400 but comparable to Heirloom red rice, NSIC Rc402, and NSIC Rc222 with 1,000-grain weight values of $26.65 \mathrm{~g}, 25.48 \mathrm{~g}$, and $24.43 \mathrm{~g}$, respectively. In terms of grain yield $\left(\mathrm{t} \mathrm{ha}^{-1}\right)$, Heirloom red rice produced significantly higher productivity of grains $\left(5.85 \mathrm{t} \mathrm{ha}^{-1}\right)$ than those of other lowland rice varieties except NSIC Rc222 with $4.63 \mathrm{t} \mathrm{ha}^{-1}$. On the other hand, NSIC Rc402 significantly produced the lowest grain yield of $4.15 \mathrm{t} \mathrm{ha}^{-}$ ${ }^{1}$ but comparable to NSIC Rc400 (4.21 t ha' $\left.{ }^{1}\right)$ and NSIC Rc216 with $4.22 \mathrm{t} \mathrm{ha}^{-1}$. The result implies that Heirloom red rice and NSIC Rc222 are suitable for planting under irrigated lowland conditions in any crop establishment without affecting its grain yield. Results were construed with the study of Kwon et al. (1992), which revealed that lowland red rice produced more tillers and dry weight than white rice under irrigated lowland conditions.

Regardless of rice varieties used, the direct row seeding method obtained the highest gross income (USD 2,012.00) and gross margin of USD 1,086.60 than that of the transplanting method that only achieved a gross income and gross margin of USD 1,676.00 and USD 759.94, respectively. Among the rice varieties tested, Heirloom red rice obtained the highest gross income of USD 2,340.00, which achieved the highest gross margin of USD 1,352.45. NSIC Rc402 received the lowest gross income and gross margin with USD 1,660.00 and USD 764.25, respectively. The variations obtained in the gross income and gross margin of five lowland rice varieties were mainly attributed to the differences in its genetic potential to produce grains.

Table 6. Cost and return analysis of five rice (Oryza sativa L.) varieties as influenced by crop establishment under irrigated lowland conditions

\begin{tabular}{lcccc}
\hline \multicolumn{1}{c}{ Treatment } & $\begin{array}{c}\text { Grain yield } \\
\left(\mathrm{t} \mathrm{ha}^{-1}\right)\end{array}$ & $\begin{array}{c}\text { Gross } \\
\text { income } \\
\text { (US Dollar) }\end{array}$ & $\begin{array}{c}\text { Total variable } \\
\text { cost (US } \\
\text { Dollar) }\end{array}$ & $\begin{array}{c}\text { Gross margin } \\
\text { (US Dollar) }\end{array}$ \\
\hline Crop establishment & & & & \\
$\mathrm{M}_{1}=$ Direct row seeding & 5.03 & $2,012.00$ & 925.40 & $1,086.60$ \\
$\mathrm{M}_{2}=$ Transplanting & 4.19 & $1,676.00$ & 916.06 & 759.94 \\
\hline Mean & 4.61 & $1,844.00$ & 920.73 & 923.27 \\
\hline Rice variety & & & & \\
$\mathrm{T}_{1}=$ NSIC Rc216 & 4.22 & $1,688.00$ & 899.50 & 788.50 \\
$\mathrm{~T}_{2}=$ NSIC Rc222 & 4.63 & $1,852.00$ & 921.67 & 930.33 \\
$\mathrm{~T}_{3}=$ NSIC Rc400 & 4.22 & $1,688.00$ & 899.17 & 788.83 \\
$\mathrm{~T}_{4}=$ NSIC Rc402 & 4.15 & $1,660.00$ & 895.75 & 764.25 \\
$\mathrm{~T}_{5}=$ Heirloom red rice & 5.85 & $2,340.00$ & 987.55 & $1,352.45$ \\
\hline Mean & 4.61 & $1,844.00$ & 920.73 & 923.27 \\
\hline
\end{tabular}




\section{Conclusions}

Irrespective of crop establishment, Heirloom red rice enhanced earlier heading and obtained the highest LAI, fresh straw yield $\left(\mathrm{t} \mathrm{ha}^{-1}\right)$, producing the highest grain yield $\left(\mathrm{t} \mathrm{ha}^{-1}\right)$. Regardless of rice variety, the rice establishment's direct row seeding method significantly augmented earlier heading and had taller plant stature and higher fresh straw yield $\left(\mathrm{t} \mathrm{ha}^{-1}\right)$. All rice varieties established under direct row seeding achieved significantly higher in almost all agronomic, yield, and yield component parameters than those adopting the transplanting method of crop establishment under irrigated lowland conditions. Regardless of rice varieties, direct row seeding produced remarkably higher grain yield and obtained the highest gross income and gross margin of USD 2,012.00 and USD 1,086.60, respectively. Heirloom red rice is the most profitable lowland rice variety under lowland conditions that eventually produced excellent grain yield $\left(5.85 \mathrm{tha}^{-}\right.$ $\left.{ }^{1}\right)$ and achieved high gross income (USD $2,340.00$ ) and gross margin of USD $1,352.45 .00$ than those of other rice varieties evaluated.

\section{Recommendations}

Direct row seeding is applicable for lowland rice establishment as an effective cost-reducing method for lowland rice production. Direct row seeding is not only a cost-effective and efficient option through labor reduction but can also shorten the time of crop establishment with the use of a drum seeder. Heirloom red rice, an irrigated lowland and upland rice cultivar (dual character), is recommended for planting during the dry season, adopting direct row seeding and transplanting methods on crop establishment.

\section{Acknowledgment}

The author is very grateful to the Department of Science, and TechnologyScience Education Institute (DOST-SEI) Accelerated Science and Technology Human Resource Development Program-National Science Consortium (ASTHRDP-NSC) for funding this study. Moreover, the author would also like to thanks Dr. Milagros C. Bales and Professor Ed Allan L. Alcober for their technical support.

\section{References}

Bañoc R.D. (2019) 'Field performance and grain quality of four rice types (Oryza sativa L.) as influenced by time of planting under rainfed lowland conditions.' MS thesis.

Visayas State University, Visca, Baybay City, Leyte, Philippines.

Bleasdale J.K.A. (1982) 'The importance of crop establishment.' Annals of applied biology. 101. pp 411- 419. https://doi.org/10.1111/j.17447348.1982.tb00841.x.

Boote K.J., Jones J.W. and Hoogenboom G. (1988) 'Research and management application of the peanut crop growth model.' Proc. Am. Peanut Res. Edu. Soc., 20, $57 \mathrm{p}$.

Chhokar R.S., Sharma R.K., Gathala M.K. and Pundir A.K. (2014) 'Effects of crop establishment techniques on weeds and rice yield.' Crop Protection, Vol. 64, 2014, pp 7-12, ISSN02612194

https://doi.org/10.1016/j.cropro.2014.05 .016 .

http://www.sciencedirect.com/science/a rticle/pii/S0261219414001793.

Ewert F. (2004) 'Modeling plant responses to elevated $\mathrm{CO}_{2}{ }^{\prime}$. How vital is the leaf area index? Ann. Bot. 2004, 93, 619 - 627 pp. 
Fageria N.K., Carvalho A.B., Santos E.P., Ferreira B. and Knupp A.M. (2011) 'Chemistry of Lowland Rice Soils and Nutrient Availability.' Communications in Soil Science and plant Analysis, 42:16, 1913-1933

pp, DOI: 10.1080/00103624.2011.5914 67.

Fikriyah V.N. (2018) 'Detecting Rice crop establishment methods using sentinel-1 multi-temporal imagery in Nueva Ecija, Philippines'. Master's thesis in geoinformation science and earth observation, Enschede, The Netherlands, 2018. Accessed: July 2, 2019.

Gangwar K.S., Gill M.S., Tomar O.K. and Pandey D.K. (2008) 'Effect of crop establishment

methods on growth, productivity, and soil fertility of rice (Oryza sativa)based cropping systems.' Indian Journal of Agronomy. 53. 102 -106 pp.

International Soil Reference and Information Center (ISRIC). (1995) 'Procedures for

Soil Analysis'. (L.P. Van Reuwijk, Editor) Wageningen, The Netherlands. 106 p.

Kaya C., Tuna L. and Higgs D. (2006) 'Effect of Silicon on Plant Growth and Mineral Nutrition of Maize Grown Under Water-Stress Conditions.' Journal of Plant Nutrition, 29:8, 1469-1480 pp, DOI: $10.1080 / 01904160600837238$.

Kumar G.S., MuthukrishnanP., Ramasamy S. and Chandaragiri K.K. (2008) 'Effect of non-conventional cultivation systems with varying nitrogen levels on growth, yield,

and water management of rice. 'Madras Agric. Journal,95(712):343 - $352 \mathrm{pp}$.

Kwon S., Smith R. and Talbert R. (1992)

'Comparative Growth and Development of Red Rice (Oryza sativa and Rice (O. sativa). Weed Science, 40(1), 57-62. doi: $10.1017 / \mathrm{S} 0043175400056952$.

Landon J.R. (1991) 'Booker Tropical Soil Manual. A handbook for soil survey and Agricultural Land Evaluation in the Tropics and Subtropics'. Longman Science and

Technical John Wiley and Sons, Inc. 605 third Avenue, New York, NY 10158. $474 \mathrm{p}$

Luh B.S. (1980) 'Rice: Production and Utilization.'AVI Pub.Westport, Connecticut, USA.

$135 \mathrm{p}$.

Mishra J.S. and Singh V.P. (2011) 'Cultivar competitiveness and weed control in zero-till dry

seeded irrigated rice (Oryza sativa

L.).' Indian Journal of Agricultural Sciences.

81(10): 978 - 78 pp.

Naklang K., Shu F. and Nathabut K. (1996) 'Growth of rice cultivars by direct seeding and Transplanting under upland and lowland conditions'. Field Crops Research, Vol. 48, Issues 2 - 3, 1996, 115-123 pp, ISSN 0378-4290, https://doi.org/10.1016/S03784290(96)01029-5.

Nelson D.W. and Sommers L.E. (1982) 'Total Carbon, Organic Carbon, and Organic Matter.' In-Page, A. L. (editor): Methods of Soil Analysis (2. edit.). Part II. Chemical and Microbiological Properties. Amer. Soc. Agron. Inc. and Soil Sci. Soc. Amer. Madison, Wisconsin, 539 - 594 pp.

Olsen S.., Cole C.V., Watanabe F.S. and Dean L.A. (1954) 'Estimation of available phosphorus in soils by extraction with $\mathrm{NaHCO}_{3}{ }^{\prime}$. USDA Cir.939. U.S. Washington. 
PCARR. (1980) 'The standard method of analysis for soil, plant tissue, water, and fertilizer.'Los Baňos, Laguna, Farm, Resource, and Systems Research Division, Philippine Council for Agriculture and Research. 194 p.

Sharma A.R. (1995) 'Direct seeding and transplanting for rice production under flood-prone lowland conditions'. Field Crop Research. Vol. 44, Issues 2-3, 1995, 129 -

137 pp, ISSN 0378-4290, https://doi.org/10.1016/03784290(95)00078-X.

Stuecker M.F., Tigchelaar M. and Kantar M.B. (2018) 'Climate variability impacts rice production in the Philippines'. PLoS ONE 13(8):e0201426. https://doi.org/10.1371/journal.pone.0 201426.

Yoshida, S. (1981) 'Fundamentals of rice crop science. International Rice Res. Inst. (IRRI),

Los Baňos, Philippines, 269.

Zheng H., Chen Y., Chen Q., Li B., Zhang Y., Jia W., Mo W. and Tang Q. (2020) 'High-density planting with lower nitrogen application increased early rice production in a doubleseason rice system'. Agronomy Journal, 10.1002/agj2.20033, 112, 1, ( 205-214). 